seem essential, therefore, that any future investigations into the aetiology of chronic bronchitis should include an intensive search for rhinoviruses along with the more routine virological and bacteriological methods.

It is widely accepted that a fourfold or greater rise in antibody titre indicates viral infection, and for this reason virologists are continually stressing the importance of sending paired sera to the laboratory to demonstrate such a rise. The importance of this practice would seem to be supported strongly by our present results, which show that certain viral antibody titres may remain at high levels for several years. This finding does not appear to be restricted to chronic bronchitics, as a recent paper from Glasgow shows similar findings in cases and matched controls (Ross et al., 1967). This persistence of antibodies in individuals over 40 years of age may be due to repeated previous infection, but this does not alter the fact that a single sample of blood sent from such a patient would be of negligible diagnostic value. On the other hand, antibody titres above the persistent levels quoted in this paper may be significant. These levels may hold true only for this laboratory, but it should be possible for each laboratory to find such a level which would be of some help to the clinician anxious to establish a diagnosis on a single sample of serum.

\section{Summary}

Sera from 20 patients with chronic bronchitis have been examined for viral complement-fixing antibodies over a period of four years. During this time 68 exacerbations occurred, but only $3(4.4 \%)$ of them could be related to viral infection.
Elevated antibody titres were found to persist over a long period of time and the significance of this finding is discussed.

We would particularly acknowledge the co-operation of the patients involved in this study. We would also thank the clinicians: Professor J. W. Crofton, Dr. H. M. McLeod, Dr. D. O. Lewis, Dr. M. E. Schonell, Dr. E. Ruth Gray, Dr. C. F. Spiers, Dr. J. Turnbull, Dr. J. D. Bell, and Dr. C. J. D. Aitken; and the health visitors: Mrs. J. T. Murray, Miss M. Graham, and Miss H. Mitchell. Mrs. M. Robertson gave invaluable secretarial assistance in the co-ordination of the trial. The bacteriological investigations were carried out by Dr. Margaret Calder. We are grateful to Professor Crofton for his continued encouragement and advice, to Professor R. Cruickshank, Dr. R. H. A. Swain, Dr. A. T. Wallace, Dr. Constance A. C. Ross, Dr. M. E. Schonell, and Dr. W. Gray for helpful criticism ; to Dr. G. E. D. Urquhart, Mrs. Hazel Cross, Mr. H. W. Moncrieff, Mr. R. S. Anderson, and Mr. T. Johnston for technical assistance ; and to Miss $M$. White for secretarial assistance. The Wellcome Trust and the Scottish Hospitals Endowment Research Trust provided generous grants.

\section{RBPERENCBS}

Bradstreet, C. M. P., and Taylor, C. E. D. (1962). Mth. Bull. Minist. Hlth Lab. Servo, 21, 96.

Calder, M. A., and Schonell, M. E. (1967). To be published.

Carilli, A. D., Gohd, R. S., and Gordon, W. (1964). New Engl. 7. Med., $270,123$.

Eadie, M. B., Stott, E. J., and Grist, N. R. (1966). Brit. med. 7., 2, 671.

Jack, I., and Gandevia, B. (1960). Amer. Rev. resp. Dis., 82, 482.

Murdoch, J. McC., Leckie, W. J. H., Downie, J., Swain, R. H. A., and Gould, J. C. (1959). Brit. med. F., 2, 1277.

Ross, C. A. C., McMichael, S., Eadie, M. B., Lees, A. W., Murray, B. A., and Pinkerton, I. (1967). Thorax. In press.

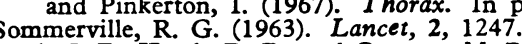

Stark, J. E., Heath, R. B., and Curwen, M. P. (1965). Thorax, 20, 124.

Tyrrell, D. A. J., and Bynoe, M. L. (1966). Lancet, 1, 76.

\title{
Trial of Ascorbic Acid in Prevention of Colds
}

\author{
GEORGINA H. WALKER,* M.B., CH.B.; M. L. BYNOE,* M.B., D.T.M.\&H. ; D. A. J. TYRRELL,* M.D., F.R.C.P.
}

Ascorbic acid is widely used as a prophylactic and therapeutic agent against the common cold, and is in fact often recommended for this purpose by medical practitioners. It may be administered as a large dose as soon as possible after the first symptoms are felt, and this dosage is then continued for a few days in order to "abort" the cold. Though many people use this treatment on themselves and believe it is effective, it is impossible to assess its efficacy. Untreated subjects may experience symptoms such as sneezing or a mild sore throat, which then disappear without going on to a full cold, and patients' assessments of their colds are much influenced by any treatment owing to the placebo effect (Diehl et al., 1938).

In these studies we attempted to show by in-vitro experiments that exposure of cells to ascorbic acid increased their resistance to infection with viruses. Though there was no activity in vitro, we also attempted to demonstrate a protective effect in animals or man, since it was thought that host resistance might be enhanced indirectly.

\section{Materials and Methods}

Virus Strains.-Strains of viruses selected from the biological groups known to cause common colds and related diseases were used (see Table I).

- From the Common Cold Research Unit, Salisbury, Wilts.
Tissue Cultures.-Roller-tube cultures were used, as follows: (1) "Diploid" human embryo lung fibroblast cells (HEL). A semicontinuous line isolated in this laboratory was used and maintained in Eagle's medium with $2 \%$ ox serum and antibiotics. (2) Monkey kidney cells (MK) ; cultures of secondary trypsinized cells were washed three times and maintained in Eagle's medium. (3) Hela cells of the Bristol line were maintained in $2 \%$ rabbit serum in Eagle's medium.

Ascorbic Acid.-Ascorbic acid for injection was added to tissue culture medium immediately before use. Preliminary experiments showed that $10 \mathrm{mg}$. of ascorbic acid/100 ml. of medium was not toxic in HEL, HeLa, or MK cells, and there was no crystal deposition. This concentration was therefore

TaBLB I.-Viruses Used in Tissue-culture Experiments with Ascorbic

\begin{tabular}{|c|c|c|c|c|}
\hline Family & & Group & Strain & $\begin{array}{l}\text { Tissue Used for } \\
\text { Propagation }\end{array}$ \\
\hline $\begin{array}{l}\text { Picornavirus } \\
\text { \#" } \\
\text { Myxovirus } \\
\text { ”, } \\
\text { Adenovirus } \\
\text { Enterovirus } \\
\text { " } \\
\text { Herpesvirus }\end{array}$ & $\begin{array}{l}\because \\
\because \\
\because \\
\because \\
\because \\
\because \\
\because\end{array}$ & $\begin{array}{l}\text { Rhinovirus H } \\
\text { „” H } \\
\text { Influenza B } \\
\text { Parainfluenza } 3 \\
\text { Respiratory syncytial } \\
\text { Adenovirus } 5 \\
\text { Poliovirus 1 } \\
\text { E.C.H.O. 11 } \\
\text { Coxsackie A21 } \\
\text { Herpes simplex }\end{array}$ & $\begin{array}{l}16 / 60 \\
\text { FEB } \\
\text { HGP } \\
\text { B Eng/101/62 } \\
\text { Prototype } \\
\text { Randall } \\
\text { Prototype } \\
\text { LSc 2ab } \\
\text { U virus } \\
\text { Local strain } \\
\text { Perrett* }\end{array}$ & 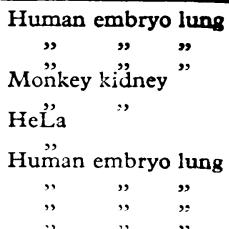 \\
\hline
\end{tabular}


used in all the tissue-culture work. The volunteers took $1 \mathrm{~g}$ of ascorbic acid three times a day as effervescent tablets supplied by Roche Laboratories. These were given for three days before virus inoculation, and for six days after. No side-effects of the treatment were observed. Control subjects were given placebo tablets which were indistinguishable from the ascorbic acid tablets except by chemical analysis.

Volunteers.-These were housed and observed as described elsewhere (Tyrrell, 1965). They ranged in age from 18 to 50 (mean 30.2 years). They received a generous mixed diet which included fresh fruit and cooked vegetables. The dietary ascorbic acid was not measured, but the trials were conducted when the general dietary intake both before and during the trials was expected to be low, so that the effects of supplements would be expected to be maximal. Two serum specimens were taken from most volunteers; the first before virus inoculation, and the second about a fortnight after inoculation. They were tested for antibodies against the virus with which the volunteer had been inoculated by neutralization in tissue culture for rhinoviruses and by haemagglutination inhibition for influenza. Nasal washings were collected daily from the volunteers for five days, from the first day after virus inoculation. Phosphate buffered saline was used to take the washings, and the specimens were either inoculated immediately into tissue-culture tubes or mixed with an equal volume of nutrient broth, stored at $-70^{\circ} \mathrm{C}$. and tested later. Representative viruses isolated from the washings were typed by neutralization tests with specific antiserum. Volunteers were inoculated with a virus which had been propagated by serial passage in volunteers. The virus was stored as nasal washing at $-70^{\circ} \mathrm{C}$. and thawed and diluted $1 / 10$ in Hanks's saline immediately before use.

Mice.-Porton strain white mice were used. They were given $4 \mathrm{mg}$. daily of a freshly prepared solution of ascorbic acid in saline or of plain saline by intraperitoneal injection for six days before and nine days after virus inoculation. Influenza $A$ (Mel) virus was administered as intranasal drops under light ether anaesthesia.

\section{Results}

\section{Experiments in Tissue Cultures}

Table II shows the results of experiments in which cells in tissue-culture tubes were exposed to medium containing ascorbic acid for one to one and a half hours before being inoculated with viruses. After inoculation the culture tubes were rolled at $33^{\circ} \mathrm{C}$. and observed daily for a cytopathic effect or, in the case of tissue infected with a myxovirus, tested several days later by haemadsorption. The minimum infectious dose for each virus was the same in treated and in untreated cultures. However, It was shown that there was a marked decrease in the ascorbic acid content of the medium within four hours of its addition to medium whether in contact with cultures or not. In one experiment with adenovirus type 5 the medium was therefore changed every 12 hours for four days, but there was still no apparent antiviral effect.

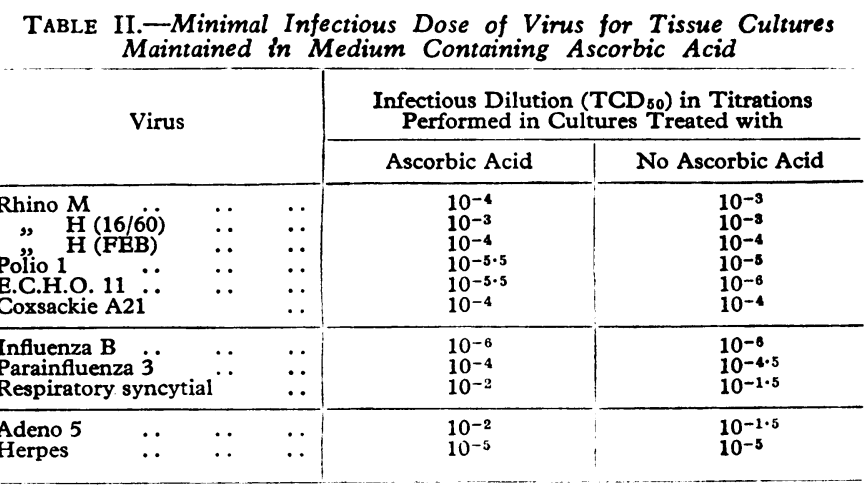

\section{Experiments on Mice}

Mice were treated with intraperitoneal ascorbic acid at a dose of about $300 \mathrm{mg} . / \mathrm{kg}$. As shown in Table III, neither the mortality rate nor the extent of the lung lesions in the survivors was reduced.

TABLE III.-Results in Mice Treated with Ascorbic Acid and Challenged with Influenza A Virus

\begin{tabular}{|c|c|c|c|c|}
\hline \multirow{2}{*}{ Treatment } & & & \multicolumn{2}{|c|}{ Dilution of Virus } \\
\hline & & & $10^{-3}$ & $10^{-4}$ \\
\hline $\begin{array}{l}\text { Ascorbic acid }\{ \\
\text { Saline }\end{array}$ & $\begin{array}{l}\text { Lung lesion score* } \\
\text { Deaths } \ldots \\
\text { Lung lesion score } \\
\text { Deaths } \quad . .\end{array}$ & $\begin{array}{l}. . \\
\cdots \\
\ldots\end{array}$ & $\begin{array}{l}12 / 16 \\
2 / 4 \\
6 / 16 \\
1 / 4\end{array}$ & $\begin{array}{l}3 / 16 \\
0 / 4 \\
3 / 16 \\
0 / 4\end{array}$ \\
\hline
\end{tabular}

\section{Experiments on Volunteers}

The experiments took place in the first five months of 1966. Volunteers received $3 \mathrm{~g}$. daily - that is, about $75 \mathrm{mg} . / \mathrm{kg}$. $/$ dayof ascorbic acid by mouth for three days before being challenged with a small dose of virus which had been passed from man to man. Table IV shows the number of volunteers who developed colds, and Table $\mathrm{V}$ the results of virus isolation studies and of antibody titrations on acute and convalescent sera.

The viruses used were drawn from all those known to be frequent causes of colds. The rhinoviruses were represented by three strains, two of which belonged to the $M$ and $H$ types, the third, H.S., being a recently described type which 'can be cultivated only in organ cultures. The B814 virus is a recently cultivated virus which is now known to be morphologically similar to avian bronchitis and to at least one other virus causing human colds (Almeida and Tyrrell, 1967); the influenza B virus is a typical myxovirus, and influenza and parainfluenza viruses cause an appreciable proportion of colds, particularly in

TABLE IV.-Clinical Response of Volunteers who received Ascorbic Acid Tablets and were then Inoculated with Viruses Capable of Causing Colds

\begin{tabular}{|c|c|c|c|c|c|c|c|c|c|}
\hline & & \multicolumn{8}{|c|}{ Results in Volunteers Receiving } \\
\hline & & \multicolumn{2}{|c|}{ Rhinoviruses } & \multicolumn{2}{|c|}{ Influenza B Virus } & \multicolumn{2}{|c|}{ B814 Virus } & \multicolumn{2}{|c|}{ All Viruses } \\
\hline & & $\begin{array}{l}\text { Ascorbic } \\
\text { Acid }\end{array}$ & Placebo & $\begin{array}{c}\text { Ascorbic } \\
\text { Acid }\end{array}$ & Placebo & $\begin{array}{c}\text { Ascorbic } \\
\text { Acid }\end{array}$ & Placebo & $\begin{array}{c}\text { Ascorbic } \\
\text { Acid }\end{array}$ & Placebo \\
\hline 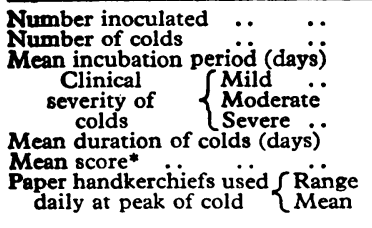 & $\begin{array}{l}\because \\
\because \\
\because \\
\because \\
\because \\
\because \\
.\end{array}$ & $\begin{array}{c}29 \\
9 \\
3 \cdot 1 \\
7 \\
\frac{2}{2} \\
7 \cdot 4 \\
6 \cdot 5 \\
4-32 \\
10\end{array}$ & $\begin{array}{c}26 \\
9 \\
2 \cdot 4 \\
7 \\
1 \\
1 \\
9 \cdot 2 \\
5 \cdot 9 \\
3-56 \\
14\end{array}$ & $\begin{array}{c}8 \\
4 \\
3 \\
1 \\
3 \\
10 \cdot 7 \\
13 \cdot 7 \\
6-82 \\
35\end{array}$ & $\begin{array}{c}8 \\
4 \\
2 \cdot 8 \\
1 \\
1 \\
2 \\
8 \cdot 5 \\
9 \cdot 2 \\
10-23 \\
17 \cdot 5\end{array}$ & $\begin{array}{c}10 \\
5 \\
3 \\
3 \\
2 \\
6 \cdot 6 \\
6 \cdot 2 \\
8-25 \\
14\end{array}$ & $\begin{array}{c}10 \\
5 \\
3 \cdot 8 \\
3 \\
\frac{2}{2} \\
4 \cdot 6 \\
7 \cdot 0 \\
7-38 \\
19 \cdot 8\end{array}$ & $\begin{array}{c}47 \\
18 \\
3 \\
11 \\
2 \\
5 \\
8 \\
8 \\
4-82 \\
16 \cdot 5\end{array}$ & $\begin{array}{c}44 \\
18 \\
2 \cdot 9 \\
11 \\
2 \\
5 \\
8 \\
7 \\
3-56 \\
16 \cdot 5\end{array}$ \\
\hline
\end{tabular}


young children. If ascorbic acid had a general prophylactic effect on colds it should have had an effect on colds produced by rhinoviruses and probably also by the other viruses used.

Table IV shows the results obtained. It indicates that the number of colds and their severity were not affected by ascorbic acid. The length of the incubation period and the duration of symptoms were variable, but the mean values of both these periods were the same in treated and untreated volunteers. In parallel with these experiments 18 volunteers received noninfectious intranasal drops and two developed a cold. In the case of two rhinoviruses and the influenza $B$ virus it was possible

TABLE V.-Results of Laboratory Tests on Volunteers Inoculated with Three Different Viruses

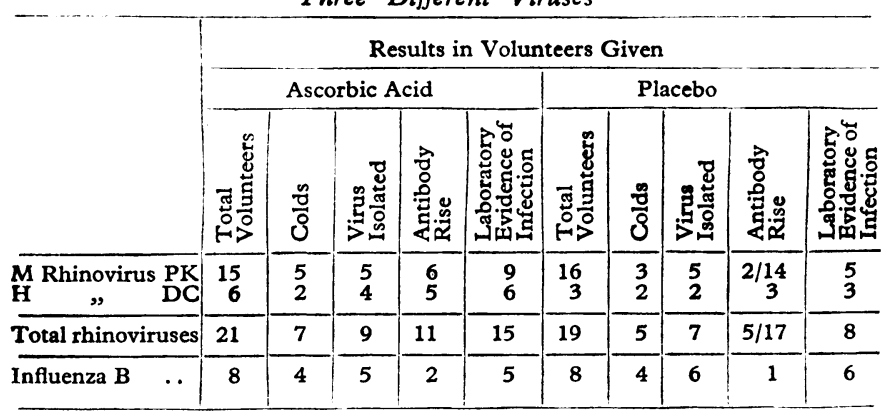

to test for virus infection, and Table $\mathrm{V}$ shows that virus infection was not reduced in frequency by the treatment. Naturally, the volunteers who were infected were drawn from the group who had low antibody titres and the number of these in each trial varied unpredictably, but there was no evidence that subjects with little or no antibody were protected from infection by ascorbic acid. We considered the possibility that the results described in the literature might be due to a rather specific effect of ascorbic acid on either the symptoms of sore throat or the occurrence of mucopurulent nasal discharge. Thirteen volunteers who developed colds while taking ascorbic acid complained of sore throat, while 15 who were on placebo tablets did so. The comparable figures for mucopurulent nasal discharge were 10 and 8 . It was concluded that there was no evidence for a general, antiviral, or symptomatic prophylactic effect of ascorbic acid in these experiments.

In two trials the volunteers were told whether or not they had been given ascorbic acid before their colds had finished, and the colds in the treated groups were appreciably shorter than in the controls; in the third and later trials they were not told which they had received, and the duration of the colds was similar in both groups. This could have been due to the effect of ascorbic acid or to coincidence, but may have been a result of therapeutic suggestion.

We wished to confirm that the vitamin was being taken and absorbed properly. Therefore, in the trial in which influenza $B$ was used a urine sample was collected from each volunteer during the incubation period. This was titrated for its ascorbic acid content by the dichlorophenol-indophenol method. No ascorbic acid was detected in the urine of nine volunteers receiving placebo, and from 28 to $126 \mathrm{mg} . / 100 \mathrm{ml}$. (mean $73 \mathrm{mg}$./ $100 \mathrm{ml}$.) was found in eight receiving the vitamin.

\section{Discussion}

In reading the literature it has been noted that conflicting claims have been made regarding the value of vitamin $C$ either alone or in combination with bioflavonoids in the prevention and treatment of acute infections of the upper respiratory tract.

Uncontrolled observations are of course impossible to evaluate, but even where placebos are used as a basis for comparison there have been many important differences between the studies reported; they have differed in the type of clinical illness occurring in the population, the day and method of clinical assessment, the age and nutritional state of the subjects, and the amount of vitamin given and whether it was administered prophylactically or therapeutically. One trial, for instance, suggested that there was a marked reduction in the duration of colds in baseball players given prophylactic vitamin C (Barnes, 1961), but the control group observed were not players.

In another controlled trial there was an apparent improvement two days after treatment in subjects given a mixture of bioflavonoids, ascorbic acid, and aspirin rather than another analgesic capsule (Macon, 1956) ; it is impossible, however, to decide which of the differences in medication accounted for the results. In another large trial (Tebrock et al., 1956) a mixture of bioflavonoids and of $200 \mathrm{mg}$. of ascorbic acid daily was given after the onset of the cold, but the clinical observations, which were made only one and three days after treatment began, showed no evidence of improvement. Other smaller trials also showed no effect. Banks $(1964,1965)$ has drawn attention to the possibility that treatment with ascorbic acid may reduce the number of colds which are followed by long-continued purulent discharge. Table VI summarizes some facts from what seem to us to be among the most critically evaluated of the earlier trials ; this supports the view that small doses of ascorbic acid administered to those on a low intake or large doses administered to those on a normal intake may reduce the duration of pharyngitis or colds.

Table VI.-Some Previous Controlled Studies on the Effect of Ascorbic

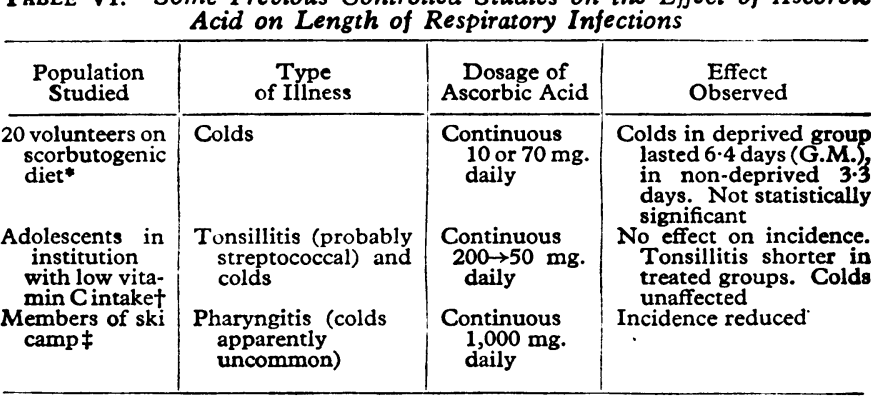

* Bartley et al. (1953). + Glazebrook and Thomson (1942). ‡ Ritzel (1961).

We thought it to be intrinsically unlikely that ascorbic acid could influence the uptake or replication of viruses. Nevertheless, the "uncoating" of viruses and the damage they produce may be mediated by the release of enzymes from lysosomes (Mallucci and Allison, 1965), and these organelles may be stabilized by ascorbic acid-at least in photosensitized epithelial cells (T. F. Slater, personal communication, 1966). It was therefore possible that the vitamin might influence the multiplication and cytopathic effect of viruses. The results of the in-vitro experiments were negative, but were not entirely convincing because of the rapid rate of inactivation of the vitamin in the cultures used. Since ascorbic acid can apparently improve the response to stress of the rat and influence the repair of skin, it might assist repair of the mucosa from the damage produced by viruses. It was therefore thought justifiable to undertake volunteer experiments with large doses of ascorbic acid administered before a known virus and a strict double-blind procedure to evaluate the clinical effects ; laboratory techniques were used to determine, when possible, which volunteers had antibodies and which were infected.

We conclude that there is no evidence that the administration of ascorbic acid has any value in the prevention or treatment of colds produced by five known viruses. The literature indicates that the administration of the vitamin to deficient subjects may reduce the incidence or severity of colds and possibly of pharyngitis due to streptococci, as well as the incidence of rheumatic fever and pneumonia (Glazebrook and Thomson, 1942). However, it is quite reasonable to conclude 
that administering very large doses of vitamin to well-nourished people does not have the same effect.

It is sometimes said that the colds produced at this unit are not comparable to those which occur in people who are exposed to natural infection and who may develop hypothetical secondary bacterial infections. We, on the other hand, are impressed with the fact that the colds observed here experimentally are very similar clinically to those, caused by the same viruses, which are observed in clinical practice (Tyrrell, 1965), and we should be surprised if ascorbic acid had any prophylactic or therapeutic value for well-nourished subjects who caught colds at home or at work.

\section{Summary}

Preliminary experiments showed no evidence that ascorbic acid protected cultures against several respiratory viruses or white mice against influenza. In further experiments 91 volunteers were given either $3 \mathrm{~g}$. of ascorbic acid daily or placebo tablets. Three days after the treatment began they received intranasal drops containing an $\mathrm{M}$ rhinovirus, an $\mathrm{H}$ rhinovirus, a "new" rhinovirus which grows only in organ cultures, influenza virus type $\mathrm{B}$, or a "new" virus related to avian bronchitis. The number, duration, and severity of the resulting colds were the same in the treated and control groups. There was no evidence that colds produced by any single virus were favourably affected.

We wish to thank Miss E. M. Bullock and Dr. B. M. Tyrrell for help with the clinical observations, and Miss P. M. Ball for technical assistance. We would also thank Dr. D. Scott, of Roche Products, for helpful discussions and for arranging a generous supply of tablets of vitamin and placebo mixtures.

\section{REFERENCES}

Albanese, M., Bynoe, M. L., and Tyrrell, D. A. J. (1966). Arch. ges. Virusforsch., 18, 356.

Almeida, J., and Tyrrell, D. A. J. (1967). F. gen. Virol. In press.

Banks, H. S. (1964). F. Col. gen. Practit., 8, 371.

- (1965). Lancet, 2, 790.

Barnes, F. E. (1961), N.C. med. 7., 22, 22.

Bartley, W., Krebs, H. A., and O'Brien, J. R. P. (1953). Spec. Rep. Ser. med. Res. Coun. (Lond.), No. 280.

Diehl, H. S., Baker, A. B., and Cowan, D. W. (1938). F. Amer. med. Ass., 11i, 1168 .

Glazebrook, A. J., and Thomson, S. (1942). 7. Hyg. (Lond.), 42, 1.

Horsfall, F. L., jun. (1939). F. exp. Med., 70, 209.

Macon, W. L., (1956). Industr. Med. Surg., 25, 525.

Mallucci, L., and Allison, A. C. (1965). 7. exp. Med., 121, 477.

Ritzel, G. (1961). Helv. med. Act, 28, 63 .

Tebrock, H. E., Arminio, J. J., and Johnston, J. H. (1956). F. Amer. med. Ass., 162, 1227 .

Tyrrell, D. A. J. (1965). Common Colds and Related Diseases. London.

\title{
Hazard of Peritoneal Dialysis: Contaminated Fluid
}

\author{
W. K. STEWART,* M.B., M.R.C.P., M.R.C.P.ED. ; D. C. ANDERSON, $\dagger$ M.B., M.R.C.P., M.R.C.P.ED. \\ MARGARET I. WILSON, $¥$ M.SC.
}

Brit. med. F., 1967, 1, 606-607

Peritoneal dialysis has become widely used, largely on account of simplicity and safety. The method became popular only after commercially prepared sterile dialysate and cannulae became available. Recent experience in Dundee has brought to light a potential hazard which merits attention. For the past two years we have used commercially prepared dialysate, supplied in 1-litre plastic containers. The inner bag containing the dialysate is itself enclosed in a thin plastic envelope. The space between the inner bag and the envelope is not sterile. During the past 18 months seven bags with small leaks at the neck have been found. In all seven an obvious mass of fungus was growing in the fluid of the inner bag (see Fig.). Five of these contaminated bags were discovered in the past five months, during which time about 3,000 litres of fluid have been used. These findings led us to examine carefully our current stock of fluid, most of which had been delivered in the immediately preceding two weeks. All containers were inspected against a bright light.

\section{Results}

Of 940 1-litre containers $19(2 \%)$ were clearly defective. One bag and envelope had collapsed completely and it was not investigated further. The remaining 18 had obvious leakage into the space between envelope and bag. The trapped fluid varied in volume from 3 to $540 \mathrm{ml}$., and was cloudy or contained mycelium on inspection. Of the 18 containers $12 \mathrm{had}$

\footnotetext{
- Senior Lecturer, Department of Medicine, Queen's College, and Artificial Kidney Unit, Maryfield Hospital, Dundee.

t Registrar, Medical Professorial Unit and Artificial Kidney Unit, Maryfield Hospital, Dundee.

₹ Lecturer, Department of Bacteriology, Queen's College, Dundee.
}

a mycelial mass varying from white to dark brown within the inner bag, and organisms were cultured from all of these. In the remaining six the fluid of the inner bag appeared clear but organisms were nevertheless cultured from two of them. Four were sterile. The organisms cultured from the inner bags, which might therefore have been introduced into the peritoneum if the existence of contamination had been missed, are listed in Table I. With only cursory inspection at the bedside at least three of these containers might easily have been passed as satisfactory. Also included in Table $I$ are the results of the cultures taken from the seven contaminated bags discovered before the survey of dialysis fluid stocks. Similar

TABLE I.-Organisms Isolated by Cultures Taken from Dialysate Within TABLE I.-Organisms Isolated by Cultures
Inner Bag of Grossly Leaking Containers*

types of organisms were grown from the fluid which had leaked and was trapped by the outer envelope of these containers. Judging by the serial numbers, the 25 containers described in Table I were derived from 11 different batches.

The 940 litres of dialysate included 540 litres of low glucose content and 400 litres of high glucose content. Gross leakage 